\title{
Gambaran Kasus Luka Tembak di Kota Manado
}

\author{
${ }^{1}$ Margareta Pabur, ${ }^{2}$ Djemi Tomuka, ${ }^{2}$ Johannis F. Mallo
}

${ }^{1}$ Program Studi Pendidikan Dokter Fakultas Kedokteran Universitas Sam Ratulangi Manado

${ }^{2}$ Bagian Ilmu Kedokteran Forensik dan Medikolegal Fakultas Kedokteran

Universitas Sam Ratulangi - RSUP. Prof. Dr. R. D. Kandou Manado

Email: paburmargareta@gmail.com

\begin{abstract}
Death and severe injury caused by firearm become an important concern worldwide. The increasing crime actions result in the increased use of firearms. In Manado, data of cases of vulnus sclopetorum (injuries or wound caused by the use of firearm) have not been well organized. This study was aimed to obtain the profile of vulnus sclopetorum in Manado. This was a descriptive retrospective study using data of vulnus sclopetorum stated in visum et repertum in Forensic Medicine and Medicolegal Department of Prof. Dr. R. D. Kandou Hospital, Bhayangkara Hospital, and Manado Police Department from January 2013 to December 2017. The results showed that there were 11 cases of vulnus sclopetorum. All cases were males, mostly in productive age, and the type of wound was infiltrated vulnus sclopetorum.
\end{abstract}

Keywords: vulnus sclopetorum, firearm

\begin{abstract}
Abstrak: Kematian dan atau luka berat yang diakibatkan oleh penggunaan senjata api telah menjadi salah satu masalah global. Tingkat kejahatan yang semakin meningkat menyebabkan penggunaan senjata api sebagai alat untuk melukai seseorang makin bertambah. Di Kota Manado sendiri, data mengenai kasus luka tembak (vulnus sclopetorum) belum terorganisir dengan baik. Penelitian ini bertujuan untuk mendapatkan gambaran luka tembak di Kota Manado. Jenis penelitian ialah deskriptif retrospektif. Dari hasil pengumpulan data kasus luka tembak di Kota Manado selama periode Januari 2013-Desember 2017 melalui penelusuran Visum et Repertum pada kasus luka tembak di Bagian Ilmu Kedokteran Forensik Medikolegal RSUP Prof. Dr. R. D. Kandou Manado, RS Bhayangkara Manado, dan Kepolisian Resor Kota Manado tercatat 11 kasus luka tembak yang terjadi di Kota Manado. Secara keseluruhan kasus luka tembak terjadi pada laki-laki, didominasi oleh usia produktif, dengan gambaran luka tembak masuk.
\end{abstract}

Kata kunci: luka tembak, senjata api

Dalam menghadapi kekerasan yang menggunakan senjata api sebagai alat yang dimaksudkan untuk melukai atau mematikan seseorang, maka dokter sebagai orang yang melakukan pemeriksaan khususnya atas diri korban mempunyai wewenang dalam melakukan pemeriksaan seperti yang tercantum dalam pasal 133 ayat (1) Kitab Undang-Undang Hukum Acara Pidana (KUHAP) dan pasal 179 ayat (1) KUHAP yang menjelaskan bahwa penyidik berwenang meminta keterangan ahli kepada ahli kedokteran kehakiman atau dokter atau bahkan ahli lainnya. Keterangan ahli tersebut adalah Visum et Repertum (VeR), dimana di dalamnya terdapat penjabaran tentang keadaan korban, baik korban luka, keracunan, ataupun mati yang diduga karena tindak pidana. ${ }^{1}$ Luka tembak adalah suatu cedera pada tubuh yang diakibatkan oleh senjata api. Senjata api menggunakan tenaga hasil peledakan mesiu dan dapat melontarkan proyektil (anak peluru) yang berkecepatan tinggi melalui larasnya. ${ }^{2}$ 
Penggunaan senjata api dalam tindak kekerasan, beberapa tahun terakhir ini meningkat. Diperkirakan terdapat lebih dari 500.000 kasus luka tembak dalam setahun. Menurut WHO pada tahun 2001, jumlah kasus tersebut mewakili seperempat dari total perkiraan 2,3 juta kematian akibat kekerasan. Dari 500.000 kasus luka tembak, $42 \%$ merupakan kasus bunuh diri, $38 \%$ merupakan kasus pembunuhan, dan $20 \%$ merupakan kasus perang dan konflik senjata. $^{3}$

Luka tembak yang disebabkan oleh penggunaan senjata api merupakan penyebab kematian yang paling umum di Amerika Serikat. Diperkirakan kasus kematian di Amerika Serikat pertahunnya sekitar 32.300 jiwa antara tahun 2007-2015. Laporan pada tahun 2014 tercatat angka kejadian luka tembak ialah 10,2/100 ribu (67\% kasus pembunuhan, 50\% kasus bunuh diri, $43 \%$ kasus perampokan, dan $21 \%$ kasus kecelakaan). Laporan dari Inggris dan Wales pada tahun 2001 mengungkapkan bahwa angka kejadian luka tembak ialah 0,4/100.000 kasus sedangkan laporan dari Kanada mengungkapkan angka kejadian luka tembak yaitu 2,6/100.000. ${ }^{4} \mathrm{Di}$ Indonesia, menurut laporan hak asasi manusia triwulan ke dua tahun 1998 yang dikeluarkan oleh Lembaga Studi dan Avokasi Masyarakat (LSAM) pada triwulan ke II, tercatat 102 warga negara yang menjadi korban kekerasan akibat senjata api. ${ }^{4}$

Laporan mengenai gambaran kasus luka tembak di Kota Manado, sampai saat ini belum terlalu lengkap. Berdasarkan hal tersebut maka dilakukan penelitian yangi bertujuan untuk mengetahui gambaran kasus luka tembak di Kota Manado.

\section{METODE PENELITIAN}

Jenis penelitian yang dilakukan ialah deskriptif retrospektif. Penelitian ini menggunakan data sekunder selang waktu Januari 2013 - Desember 2017 di Bagian Ilmu Kedokteran Forensik dan Medikolegal RSUP Prof. Dr. R. D. Kandou Manado dan Kepolisian Resor Kota Manado.

Subjek penelitian ialah data kasus luka tembak akibat kekerasan senjata api dan surat keterangan Visum et Repertum (VeR) di Bagian Ilmu Kedokteran Forensik dan Medikolegal Fakultas Kedokteran Universitas Sam Ratulangi - RSUP Prof. Dr. R. D. Kandou Manado dan Kepolisian Resor Kota Manado selama periode Januari 2013 - Desember 2017.

\section{HASIL PENELITIAN}

Hasil penelitian yang dilakukan di Bagian Ilmu Forensik Medikolegal FK Unsrat - RSUP Prof. Dr. R. D. Kandou Manado dan Kepolisian Resor Kota Manado menggunakan metode retrospektif didapatkan sebanyak 11 kasus luka tembak yang terjadi di Kota Manado dengan rincian sebagai berikut: 2 kasus $(18,18 \%)$ di tahun 2013, 3 kasus $(27,27 \%)$ di tahun 2014, 1 kasus $(9,09 \%)$ di tahun 2015, 4 kasus $(36,36 \%)$ di tahun 2016, dan 1 kasus $(9,09 \%)$ di tahun 2017 (Tabel 1).

Tabel 1. Sebaran kasus luka tembak di Manado periode Januari 2013 - Desember 2017

\begin{tabular}{ccc}
\hline Tahun & Jumlah kasus & $\boldsymbol{\%}$ \\
\hline 2013 & 2 & 18,18 \\
2014 & 3 & 27,27 \\
2015 & 1 & 9,09 \\
2016 & 4 & 36,36 \\
2017 & 1 & 9,09 \\
Total & 11 & 100 \\
\hline
\end{tabular}

Tabel 2 memperlihatkan karakteristik sosiodemografik kasus luka tembak. Kejadian ini lebih banyak terjadi pada laki-laki $(100 \%)$ sedangkan pada perempuan hanya sedikit sekali bahkan sangat jarang. Kasus luka tembak sendiri umunya terjadi pada rentang usia $25-44$ tahun yaitu $9(81,81 \%)$ kasus, dan hanya sebagian kecil terdapat pada rentang usia 15-24 tahun yaitu 2 $(18,18 \%)$ kasus, sedangkan untuk usia $<5$ tahun dan 5-14 tahun, 45-64 tahun dan $>65$ tahun tidak dijumpai kasus luka tembak.

Dari keselurahan kasus hanya 2 kasus yang dibawa ke Bagian Kedokteran Forensik dan Medikolegal RSUP Prof. Dr. R. D. Kandou Manado; keduanya dalam keadaan meninggal dunia. Karakteristik 
kedua korban tersebut dapat dilihat pada Tabel 3. Kedua korban memiliki jenis kelamin dan gambaran luka tembak yang sama tetapi lokasi luka yang berbeda. Pada kasus pertama korban berjenis kelamin laki-laki, berusia 26 tahun dengan lokasi luka pada lengan atas kanan yang masuk ke rongga dada dan melubangi paru kanan serta pembuluh nadi leher kanan. Pada kasus kedua korban berjenis kelamin lakilaki, berusia 22 tahun dengan lokasi luka pada dada kanan.

Tabel 2. Sebaran karakteristik sosiodemografik luka tembak di Manado periode Januari 2013Desember 2017

\begin{tabular}{ccc}
\hline Karakteristik & Jumlah & $\%$ \\
\hline Jenis kelamin & & \\
Laki-laki & 11 & 100 \\
Perempuan & 0 & 0 \\
Usia (tahun) & & \\
$<5$ & 0 & 0 \\
$5-14$ & 0 & 0 \\
$15-24$ & 2 & 18,18 \\
$25-44$ & 9 & 81,81 \\
$45-64$ & 0 & 0 \\
$>65$ & 0 & 0 \\
\hline
\end{tabular}

Tabel 3. Karakterisitik sampel korban luka tembak

\begin{tabular}{ccc}
\hline Variabel & $\begin{array}{c}\text { Kasus } \\
\text { pertama }\end{array}$ & $\begin{array}{c}\text { Kasus } \\
\text { kedua }\end{array}$ \\
\hline $\begin{array}{c}\text { Jenis } \\
\text { kelamin } \\
\text { Usia }\end{array}$ & Laki-laki & Laki-laki \\
Lokasi & 26 tahun & 22 tahun \\
luka & Lengan kanan & Dada kanan \\
$\begin{array}{c}\text { Gambaran } \\
\text { luka }\end{array}$ & $\begin{array}{c}\text { Luka tembak } \\
\text { masuk }\end{array}$ & $\begin{array}{c}\text { Luka tembak } \\
\text { masuk }\end{array}$ \\
\hline
\end{tabular}

Tabel 4 memperlihatkan karakteristik jenis luka tembak. Terdapat dua kasus yang dibawa ke Bagian Ilmu Kedokteran Forensik dan Medikolegal RSUP Prof. Dr. R. D. Kandou Manado. Kedua kasus ini memiliki data jenis luka tembak, dan seluruhnya (100\%) ialah jenis luka tembak masuk.
Tabel 4. Karakteristik luka tembak berdasarkan gambaran luka tembak

\begin{tabular}{ccc}
\hline $\begin{array}{c}\text { Karakteristik } \\
\text { jenis luka }\end{array}$ & Jumlah & \% \\
\hline Luka tembak masuk & 11 & 100 \\
Luka tembak keluar & 0 & 0 \\
\hline
\end{tabular}

\section{BAHASAN}

Penelitian ini menggunakan metode retrospektif menggunakan data selama kurun waktu 2013-2017 di Manado dan ditemukan sebanyak 11 kasus luka tembak. Kasus terbanyak terjadi pada tahun 2016 yaitu sebanyak 4 kasus. Dibandingkan dengan daerah lain, kejadian luka tembak di Manado cenderung lebih sedikit. Menurut laporan Komisi untuk Orang Hilang dan Tindak Kekerasan (KontraS), pada Agustus 2018 di provinsi Papua tercatat sebanyak 110 kasus penembakan dalam kurun waktu 4 tahun, sedangkan di Provinsi Nanggroe Aceh Darussalam, tercatat sejumlah 22 kasus penembakan dalam kurun waktu 3 tahun. ${ }^{5}$

Menurut Kepolisian Resor Kota Manado, kasus penembakan terjadi akibat dari maraknya kasus kejahatan yang bertambah. Dari banyak kasus yang terjadi, penembakan dilakukan oleh aparat keamanan. Seiring perkembangan jaman, diduga para pelaku semakin berani memberikan aksi perlawanan yang bisa mengancam keselamatan berbagai pihak. Oleh karena itu, aparat keamanan melakukan penembakan terhadap pelaku kejahatan sesuai standar operasional prosedur (SOP) yang berlaku. Tidak terdapat kasus luka tembak yang dilakukan oleh warga sipil atau masyarakat. Umumnya kasus kekerasan yang terjadi di kalangan masyarakat masih menggunakan senjata tajam atau senjata tradisional lainnya.

Dari keseluruhan data yang didapatkan, semua kasus penembakan terjadi pada laki-laki. Hal ini mungkin disebabkan beberapa faktor antara lain secara teoritik, laki-laki memiliki sex determining region $Y$ (SRY), yang dapat memengaruhi tingkat agresifitasnya dalam merespon suatu hal. Faktor tersebut turut memengaruhi respon 
laki-laki terhadap suatu kondisi terutama bila dipicu dengan munculnya stresor. Dalam hal ini laki-laki lebih rentan terlibat dalam berbagai kasus krminal. ${ }^{6}$

Dari data usia didapatkan bahwa kasus penembakan lebih banyak terjadi pada usia produktif. Pada usia produktif (25-45 tahun), setiap individu memiliki tingkat aktivitas yang tinggi. Selain tingginya aktivitas, kelompok usia produktif memiliki kemungkinan berinteraksi lebih banyak dengan berbagai kalangan sehingga lebih rentan terpaparaoleh hal negatif yang bisa dipengaruhi oleh lingkungan, pola sosialisasi antar individu, serta pengaruh stresor. ${ }^{6}$

Dari keseluruhan kasus didapatkan dua korban dalam keadaan meninggal yang dibawa ke Bagian Ilmu Kedokteran Forensik dan Medikolegal RSUP Prof. Dr. R. D. Kandou Manado. Probabilitas korban hidup ataupun meninggal tergantung pada beberapa faktor. Pertama, faktor perlawanan dan agresifitas perilaku kriminalitas. Semakin besar perlawanan dan sikap agresif yang diperlihatkan, maka aparat keamanan akan melepas tembakan sesuai dengan standar operasional prosedur (SOP) yang berlaku. Kedua, jenis tembakan yang dilontarkan. Jenis luka tembak yang dihasilkan dapat berbeda tergantung dari jarak tembak atau jarak moncong senjata dengan tubuh korban. ${ }^{7}$

Dari 11 kasus luka tembak yang terjadi di Kota Manado, hanya dua kasus yang masuk ke Bagian Ilmu Kedokteran Forensik dan Medikolegal RSUP Prof. Dr. R. D. Kandou Manado. Korban penembakan lainnya kemungkinan dibawa ke Rumah Sakit Polisi untuk dilakukan pemeriksaan lebih lanjut atau autopsi bila korban meninggal. Dari kedua kasus tersebut didapatkan korban telah meninggal. Lokasi luka tembak yang didapat yaitu mengenai bagian lengan atas (1 kasus) dan bagian dada (1 kasus). Keduanya memiliki jenis luka tembak masuk. Luka tembak masuk merupakan suatu keadaan dimana peluru masuk pada suatu objek dan tidak keluar. Salah satu ciri dari luka tembak masuk ialah terbentuknya kelim lecet (abrasion ring) yang terjadi akibat gerakan rotasi peluru yang menimbulkan gesekan antara badan peluru dengan tepi robekan kulit. ${ }^{8,9}$

Data dari Kepolisian Resor Kota Manado melaporkan bahwa belum ada kasus penembakan yang dilakukan oleh warga sipil atau masyarakat. Biasanya penembakan dilakukan oleh anggota kepolisian selaku aparat keamanan yang melakukan pengamanan sesuai dengan SOP yang berlaku. Tata cara penggunaan senjata api bagi anggota polisi diatur dalam Perkapolri No. 8 Tahun 2009 tentang Implementasi Prinsip dan Standar Hak Asasi Manusia dalam Penyelenggaraan Tugas Kepolisian Negara Republik Indonesia serta Perkapolri No. 1 tahun 2009 tentang Penggunaan Kekuatan dalam Tindakan Kepolisian. Berdasarkan pasal 47 Perkapolri 8/2009 disebutkan bahwa penggunaan senjata api hanya boleh digunakan apabila benar-benar diperuntukan untuk melindungi nyawa manusia, melindungi diri, membela orang lain terhadap ancaman kematian dan/atau luka berat. Pada dasarnya penggunaan senjata api merupakan upaya terakhir untuk menghentikan tindakan pelaku kejahatan atau tersangka. Jadi penggunaan senjata api oleh polisi, hanya digunakan saat keadaan adanya ancaman terhadap jiwa manusia. Sebelum menggunakan senjata api, polisi harus memberikan peringatan yang jelas. Tata cara pemberian peringatan diatur dalam pasal 48 Perkapolri 8/2009. Prosedur pertama yakni menyebutkan dirinya sebagai petugas yang sedang bertugas, memberi peringatan dengan ucapan secara jelas dan tegas kepada sasaran untuk berhenti, angkat tangan, atau memberi waktu meletakan senjata dan mematuhi perintah. Selain itu sesuai dengan pasal 15 Perkapolri 15/2009, sebelum melepaskan tembakan, polisi harus membuang tembakan peringatan ke udara atau ke tanah dengan kehati-hatian tinggi dengan tujuan untuk menurunkan moril pelaku serta memberi peringatan sebelum tembakan diarahkan kepada pelaku. Pengecualiannya yaitu dalam keadaan yang sangat mendesak dimana penundaan waktu diperkirakan dapat mengakibatkan kematian atau luka berat pada petugas atau orang 
lain disekitarnya, tembakan peringatan tidak perlu dilakukan. Berdasarkan data yang diperoleh dari Kepolisian Resor Kota Manado, penggunaan jenis senjata api yang digunakan dalam proses penangkapan ialah senjata api berjenis laras pendek, jenis revolver dengan kaliber $38 .{ }^{10}$

\section{SIMPULAN}

Berdasarkan hasil penelitian ini dapat disimpulkan bahwa di Kota Manado, kasus luka tembak ditemukan pada jenis kelamin laki-laki, dominan terjadi pada usia produktif, dengan jenis luka yang didapat ialah luka tembak masuk

\section{SARAN}

Dibutuhkan kerja sama yang berkesinambungan dengan pihak kepolisian terkait penelusuran kasus penembakan melalui data kronologis kasus yang lebih lengkap. Perlu dilakukan pengambilan data di Rumah Sakit Kepolisian untuk mendapatkan informasi yang lebih lengkap.

\section{DAFTAR PUSTAKA}

1. Small arms and global health. Geneva: World Healt Organization, 2011.

2. Parjaman. Catatan Ilmu Kedokteran Forensik. Bandung: Fakultas Kedokteran Uni- versitas Padjajaran, 1980.

3. Sampurna B, Samsu Z, Siswaja TD. Peranan ilmu forensik dalam penegakan hukum. MJI. 2008;17(3):210-5.

4. Iwan A, Nila N, Muhamad A. Ilmu Kedokteran Forensik dan Medikolegal. Jakarta: Raja Gravindo Persada, 2017.

5. Komisi untuk Orang Hilang dan Tindak Kekerasan (KontraS). Laporan kasus luka tembak dalam kekerasan. Jakarta, 2018.

6. Hueske E. Firearms and Tool Mark The Forensic Laboratory Handbooks, Practice and Resource. New Jersey: Humana Press, 2006.

7. Abdul I. Pedoman Ilmu Kedokteran Forensik. Jakarta: Bina Rupa Aksara, 2014.

8. Idris AM. Pedoman Ilmu Kedokteran Forensik (1st ed). Jakarta: Binarupa Aksara, 1997.

9. Umboh R, Mallo N, Tomuka D. Pola luka pada korban mati akibat senjata api di Bagian Ilmu Kedokteran Forensik Medikolegal FK Unsrat - RSUP Prof. Dr. R. D. Kandou Manado periode Januari 2007- Desember 2013 [Skripsi]. Manado: Universitas Sam Ratulangi; 2015.

10. Kepolisian Negara Republik Indonesia. Peraturan Kepala Kepolisian Negara Republik Indonesia No. 8 Tahun 2009 dan No. 1 Tahun 2009. 